\title{
LA RISA Y EL TIEMPO EN LOS EJÉRCITOS DE EVELIO ROSERO
}

\author{
POR \\ Laura García-Moreno \\ San Francisco State University
}

La violencia y la inseguridad cotidiana, a menudo pero no exclusivamente ligada al narcotráfico, es un tema frecuente en cierta rama de la ficción latinoamericana actual (en Colombia y México, por ejemplo), que ha tenido divulgación tanto local como internacional. En "Dislocaciones y otras violencias en el circuito transnacional de la literatura latinoamericana", Maria Helena Rueda examina la circulación transnacional de ficción latinoamericana sobre violencias locales, resaltando el riesgo de fetichización de la violencia que esta circulación conlleva. ${ }^{1}$ A continuación exploro el modo particular en que Evelio Rosero aborda esta cotidianidad en Los ejércitos, novela que nos sumerge en el deterioro acelerado de San José y sus habitantes, narrado desde la perspectiva de un maestro jubilado, Ismael Pasos, y su manera de responder a los retos expresivos y narrativos que presenta ya que, ante el colapso de una sociedad en que la violencia se naturaliza, el acto mismo de escribir se vuelve un reto. Organizado en cuatro secciones en que se desarrollan aspectos sobresalientes de la novela (la mirada, el tiempo, la risa, el papel de la ficción), el artículo propone que más que participar en la fetichización sobre la que Rueda advierte, Los ejércitos contribuye a reeducar la mirada del lector respecto a la misma. Como menciono más adelante, la relación observador/observado, recurrente en el interior de la obra de Rosero, recae en el lector y hace pensar o cuestionar cómo leer o mirar sus mundos literarios, específicamente, la violencia que se escenifica en Los ejércitos. En qué medida, uno no puede dejar de preguntarse al leer Los ejércitos, somos simples voyeristas de la mutilación y violación de seres y lugares, de la condición vivida por los personajes, para quienes cuerpo, casa, pueblo, todo lo considerado como propio o íntimo, ha dejado de serlo. Para confrontar realidades sociales contemporáneas específicas a Colombia que trabaja en Los ejércitos y que incluyen el vaciamiento de la subjetividad, del significado y del poder del Estado y de otras autoridades - ni el General

La violencia y sus huellas, también de Rueda, y Sitios de contienda de Juana Suárez exploran los vínculos entre la práctica de la violencia y los relatos en los cuales se narra dicha violencia en el contexto específico de Colombia. 
Palacios ni la policía ni el Padre Albornoz son capaces de brindar protección a los ciudadanos- Rosero desarrolla estrategias narrativas específicas: la desfamiliarización de un manojo de imágenes que funcionan como hilos narrativos, la indistinción de tiempos verbales, la alternancia entre el nombre y la anonimidad y la elaboración de múltiples matices de la risa. Tanto la novela como la risa en la novela son formas de confrontar el miedo, de buscar darle una forma así como una salida "a la parálisis de muerto" (106) en que se hunden tanto el protagonista como el pueblo.

Enmarcada entre una frase en pretérito al inicio -"Y era así"- y una en futuro al final -“así será"- Los ejércitos nos presenta con una situación no sólo de secuestros, desplazamientos forzados y destrucción física de cuerpos y espacios, sino también de un desajuste simbólico radical que exige nuevas aproximaciones narrativas. Una violencia indiscriminada generada por múltiples ejércitos que no se nombran, asola a los habitantes de San José. ${ }^{2}$ La violencia invade y contamina todo, no sólo plazas, calles y jardines, sino hasta lo más intímo de los personajes: pensamientos, emociones, memoria, percepción, conciencia y capacidad auto-reflexiva, la noción del tiempo y el lenguaje mismo. La frontera entre lo público y lo privado se borra; el muro que separa casa, jardín y calle se cae literal y metafóricamente. Todo se trastoca de modo que ocurre una inversión perversa de lo habitual y el horror: lo habitual se vuelve lo siniestro y lo perturbador y el horror se vuelve lo habitual, la violencia la norma. Lo impredecible (el futuro) se vuelve predecible y lo predecible (la muerte) se vuelve el objeto de deseo. En resúmen, lo familiar (rostros, calles, nombres, vecinos, el sentido del "yo") se vuelve ajeno y lo que queda es un paisaje de escombros y despojos, incluyendo a los personajes a los que se refiere continuamente como espectros, sombras o silhuetas.

Si bien el pueblo es ficticio, a través de este "pueblo en un país en el suplicio" (60), claramente se alude a la violencia que ha desgarrado a Colombia desde hace varias décadas por múltiples razones políticas, ecónomicas y sociales. Al no diferenciar ni especificar quienes son los agentes de violencia, como lo indica el título, ni detenerse con detalle en posibles causas o razones, la atención cae en el daño físico y psicológico perpetuado sobre la población civil, en la naturalización de la violencia y en la indiferencia que genera la cotidianidad de una experiencia que en otras circunstancias se consideraría una anomalía. El feto encontrado en el basurero o el hombre comiendo un helado que muere asesinado en la estación de autobuses donde Ismael conoce a su esposa Otilia por primera vez sin que nadie se inmute son ejemplos de la indiferencia ante la vida.

La falta de distinción entre los ejércitos corresponde con una observación que hace Juana Suárez respecto al carácter homogéneo que ha adquirido el terror sobre todo en ciertas regiones de Colombia: "Para los campesinos y los habitantes de zonas rurales (principales víctimas del conflicto), cualquiera de estos grupos uniformados es lo mismo" (28); "el caracter homogéneo del terror que adjudica el uniforme refuerza cierta aura espectral y anónimo que ha tenido la violencia" (28). Esta observación resulta particularmente relevante dada la dimensión espectral frecuente no sólo en Los ejércitos sino en la obra de Rosero.

Revista Iberoamericana, Vol. LXXXI, Núm. 250, Enero-Marzo 2015, 141-157 ISSN 0034-9631 (Impreso)

ISSN 2154-4794 (Electrónico) 
¿Cuál sería la función de la ficción según Rosero, bajo circunstancias en que la violencia se ha vuelto una costumbre paralizante y " $[. .$.$] el temor de resultar mal$ interpretado, de terminar acusado por este o ese ejército, de ingestar a un capo del narcotráfico" (93) conlleva el riesgo de enmudecer o quedar reducido "a un concierto balbuceos", como ocurre con el Padre Albornoz en la novela? La dificultad de hablar de lo que se vive se menciona varias veces: “[...] no se lo conté a nadie, para no meterme en problemas" (46); "resulta delicado averiguar demasiado" (65). Cómo salir del enmudecimiento que en parte resulta de "el temor de ser mal interpretado" (93) y de la indiferencia "vieja y feliz" (28) que genera la violencia diaria, cómo narrarla, y cómo aprender a mirar de nuevo, parecen ser tareas urgentes para el escritor. En un momento, ya entrada la novela, Ismael logra hacer hablar a Eusebito, el hijo de su vecina Geraldina, cuando éste regresa enmudecido después de ser secuestrado. Cabe preguntarse si la novela logra algo similar: salir de la mudez en que el horror hunde a la población y de la condición de espectros a la que todos, tanto soldados como civiles, tanto agresores como agredidos, han sido reducidos. Paula María Marín Colorado se pregunta algo parecido: ¿Cómo logra Rosero salir de la inmovilización histórica en su obra novelística? (140) y recurre principalmente a ideas de Ricoeur y de Kristeva sobre la relación con el pasado en búsqueda de una respuesta. Importante como me parece su lectura, me interesan otros aspectos. Si puede decirse que Rosero ofrece alguna pauta sobre cómo resensitivizarse, cómo desespectralizarse y dejar de ser meras sombras o muertos en vida, ¿de qué medios narrativos se vale para hacerlo?

Mabel Moraña y Héctor Hoyos han resaltado la dimensión afectiva de la novela a la que atribuyen su efectividad. Los ejércitos, señala Moraña en "Violencia, sublimidad y deseo," "construye un campo emocional" (190), "despl[iega] una serie inolvidable de escenas" (193), como el cadáver violado de Geraldina al final de la novela o la cabeza de Oye en el aceite hirviente donde solía freir sus empanadas. Hoyos declara que la novela "escenifica afectos" y propone al lector "un horror distinto" al que ofrecen los medios y de este modo logra "interrumpir las prácticas afectivas de la producción mediática de la violencia” (293). ${ }^{3}$ Escenificación e intensificación de afectos son los elementos principales que resaltan estas dos lecturas. Concuerdo con ellas ya que son estos elementos los que le permiten a Rosero acercarnos a la experiencia del horror y a hacer una distinción entre el trabajo de la ficción respecto a la violencia y el periodismo u otros medios masivos de comunicación, tema que Claudia María Maya Franco examina. Otros recursos de los que se vale Rosero para abordar la crisis perpetua en la que viven los personajes son el trabajo con el tiempo narrativo y el desarrollo de

3 En su postscríptum a la colección de ensayos, El lenguaje de las emociones, Mabel Moraña ve el estudio de la afectividad como una "vertiente de la crítica cultural" (313) que presenta "alternativas nuevas en la interpretación de lo social" (314) y encierra el potencial de abrir "a la creatividad de la resistencia y el cambio" (326).

Revista Iberoamericana, Vol. LXXXI, Núm. 250, Enero-Marzo 2015, 141-157 ISSN 0034-9631 (Impreso)

ISSN 2154-4794 (Electrónico) 
múltiples matices de la risa a lo largo de la novela (podrían añadirse aquí la ironía, el sarcasmo y la parodia), que funciona como uno de los hilos narrativos principales y contribuye a estructurar la novela. Estos elementos son aspectos claves de un esfuerzo por interrumpir la sensación de vivir dominado en un tiempo paralizado que resulta de la ubicuidad de la violencia y la familiarización con la muerte, parte de un intento por habitar un presente vaciado de sentido y dirección, y darle forma narrativa.

Un primer paso para evocar, quizá contrarrestar o por lo menos sacudir la sensibilidad del lector hacia la violencia que asola a San José, es comunicar un sentido de la cotidianeidad de los personajes y los trastornos que sufren los habitantes entre más avanza la novela. Para esto Rosero se vale de un puñado de imagenes y motivos aparentemente sencillos que introduce desde el principio. Estos se van transformando a lo largo de la novela hasta ser sometidos a una desintegración brutal. En la escena en el jardín con la que abre Los ejércitos, guacamayas, gatos, peces, naranjas y el cuerpo de Geraldina son elementos que evocan un pequeño paraíso terrenal. Una vez que la violencia penetra en todos los resquicios de la vida en San José, todos estos objetos quedan grotescamente contorsionados o destrozados. La piscina se convierte en un foso lleno de plumas y cadáveres flotantes, las naranjas revientan y quedan como manchas salpicadas en un cuadro abstracto, el cuerpo sensual de Geraldina, inicialmente cargado de erotismo, termina como un cadáver violado múltiples veces, un objeto inerte comparable a esas muñecas violentadas y distorsionadas creadas por el artista alemán Hans Bellmer en la década de los treinta.

Lo que sucede con rostros, cuerpos, lugares y objetos, también ocurre con la mirada y con expresiones no lingüísticas como la risa. Si Los ejércitos abre con una referencia a la "dulce risa" de las guacamayas en la primera oración, cierra con la risa desoladora que Ismael planea soltar ante sus agresores en el instante en que apuntan un arma contra él. Estos ejemplos son parte de la táctica de desfamiliarización y alienación de lo cotidiano que Rosero comparte con su compatriota, Doris Salcedo, artista gráfica cuyas instalaciones, sobre todo aquellas realizadas durante los noventas, incluyen objetos domésticos familiares (mesas, sillas, zapatos), que pierden su familiaridad y se vuelven insólitos al ser violentados y marcados tanto por fracturas simbólicas como por gestos de sutura y reparo. Huesos quebrados, cadáveres desfigurados, relojes astillados en Los ejércitos enfatizan el desmembramiento de individuo y sociedad así como los armarios encementados, las camisas atravesadas por una barra de metal o las mesas rotas unidas por cabello humano y fragmentos de seda de Salcedo.

A través de estas imágenes, Rosero comunica claramente una idea del deterioro aceleardo que vive San José. A su vez desmantela estereotipos de lugares o tiempos pasados en términos de utopías o paraísos, como se sugiere con la escena inicial en el jardín que, a pesar de su apariencia idílica, está plagado desde el interior por el peso contundente de la violencia y de la historia. Marín Colorado sugiere asertadamente que

Revista Iberoamericana, Vol. LXXXI, Núm. 250, Enero-Marzo 2015, 141-157 ISSN 0034-9631 (Impreso)

ISSN 2154-4794 (Electrónico) 
en todas las novelas de Rosero, "el locus amoenus primigenio es agredido" (142). En este espacio lo primero que vemos hacer al narrador es mirar.

\section{MiRADA}

La mirada voyerística de Ismael, ya señalada por Moraña y Hoyos, llama la atención desde el primer párrafo. La primera vez que conocemos al protagonista narrador está montado en una escalera observando a la vecina desnuda mientras se asolea. Como lectores vemos mirar a uno cuya mirada recae o en cuerpos femeninos o en el horror, lo cual subraya la convergencia de erotismo y violencia, como queda claro desde el inicio cuando el meneo de las caderas de Gracielita es punteado por la presencia del cuchillo "como ensangrentado" que destaca entre sus manos enjabonadas mientras lava los platos. "La violencia está erotizada" (Hoyos 289) y el erotismo está cargado de violencia, al igual que la percepción y la sensorialidad. El cuerpo de Geraldina lo dice todo: inicialmente objeto de sensualidad y deseo sobre quien cae la mirada lasciva de Ismael, Geraldina termina siendo un cadaver violado en que se fusionan grotescamente erotismo y violencia, binario inseparable que parece configurar la masculinidad bajo las condiciones en que vive el narrador (Moraña 191).

Ante todo, lo que hace Ismael es mirar, frecuentemente sin ser mirado, en contraste con otros personajes como Otilia, Geraldina o Eusebito, que miran sin mirar: "[Otilia] se dedicó a tomar café y mirar por la ventana, sin mirar. ¿Qué podía mirar? Era la noche” (54); cuando después de haber sido secuestrado, el hijo de Geraldina regresa, aparece enmudecido, "escucha sin escuchar, mira sin mirar, [...] no responde a ninguna voz" (121). Como otros personajes masculinos solitarios de Rosero, que también suelen mirar sin ser mirados, Ismael no es un testigo neutral o distanciado de lo que sucede a su alrededor, lo cual contrasta con la mirada "ajena, externa, no participativa" de los periodistas que llegan a San José (Maya Franco 240). Varios protagonistas de Rosero actuán a la vez como testigos y párticipes de su alrededor, un mundo en ruinas, en el caso de Ismael, narrador afectado por lo que narra y enfrentado al problema de cómo salir del enmudecimiento y la indiferencia, cómo mirar y narrar lo que se mira: vestigios, escombros. ${ }^{4}$ Inicialmente la mirada de Ismael tiende a ser de caracter sensual y recae

\footnotetext{
4 Al igual que Ismael, Jeremías en El lejero o el desnudo en Señor que no conoce la luna, quien observa al mundo desde un agujero en el armario, son observadores que frecuentemente miran sin ser mirados. En Muertes de fiesta Eduardo observa a Alegría mientras Lorena y Paredes observan a otros por una pantalla, también sin ser vistos. Todos ellos son voyeristas, mirones, fisgones. Sin embargo, como en el cuento corto, "Los encierros", donde quien observa a los encerrados pasa a ser un encerrado, el observador inicial es también observado, como en el caso de Otilia, que se refiere a si misma en relación a Ismael como "espía del espía" (26). Con Ismael definitivamente no se trata de un observador distanciado o neutral, inmune a lo que mira. A menudo lo encontramos hablándose a si mismo, lo escuchamos pensar.
}

Revista Iberoamericana, Vol. LXXXI, Núm. 250, Enero-Marzo 2015, 141-157 ISSN 0034-9631 (Impreso)

ISSN 2154-4794 (Electrónico) 
en cuerpos femeninos, sobre todo en Geraldina, pero esta mirada lujoriosa, que sirve de contrapeso a la muerte, débil señal de vida entre tanto muerto, eventualmente se concentra en lo que sucede con la comunidad, en las calles y personas que se vuelven desconocidas a raíz de la catástrofe, como lo confirman sus palabras una vez que decide quedarse en el pueblo: "de cualquier manera haré de este pueblo mi casa y pasearé por ti, pueblo, [...] reconoceré sus historias según sus vestigios [...]” (194).

TIEMPO

Además de huesos, miradas y vidas dislocadas, otro de los elementos profundamente trastocados por la recurrencia de la violencia en Los ejércitos es el tiempo. Así como no hay diferencia entre los distintos ejércitos y se borra progresivamente la distinción entre espacio público y privado, también se borra la diferencia entre antes y después, entre pasado, presente y futuro. Uno de los vínculos que Marín Colorado observa entre las obras de Rosero es precisamente "la presencia de una temporalidad inalterable" (138). Por su repetición histórica, la violencia, "una carga de más de doscientos años" (37), que puede trazarse a las guerras de Independencia, parece haber adquirido un carácter estructural. He aquí uno de sus efectos más violentos. Entre más rutinaria se vuelve la violencia, más difícil se vuelve distinguir entre tiempos y se elimina así la posibilidad de imaginar un futuro distinto. El tiempo se vuelve uno solo, como se hace evidente con la imagen del reloj astillado después de la explosión de la granada, que coincide con la imagen de los troncos resquebrajados de los árboles en el jardín: "Un estruendo mayor nos remece, desde el huerto mismo; el reloj octagonal de la sala [...] se ha escindido en mil líneas, la hora detenida para siempre en las cinco en punto de la tarde" (101). El reloj y el árbol hechos añicos corroboran la presencia de una fractura irreversible tanto en la naturaleza como en el orden social.

En su deambular sin rumbo por el pueblo Ismael pierde el sentido del tiempo: "perdí la cuenta de los días" (153). Más de una vez se pregunta "cuánto tiempo ha pasado?" (105) y afirma no estar seguro de estar muerto o no; deja de registrar "a qué horas pasó el tiempo", pregunta ante la cual se contesta a si mismo: "Pasó igual, pasó, igual que siempre" (65). La repetida referencia a la indiferenciación de tiempos ligada a la violencia -como le dice el doctor Orduz a Ismael, "lo que ocurre hoy, como ocurre desde ayer, y ocurrirá mañana, para desgracia de este pueblo en pena" (90)- subraya el modo en que la violencia sin límite aniquila la posibilidad de que el tiempo se destienda y ramifique, de distinguir entre ayer, hoy y mañana, o vislumbrar un futuro que abriera otra línea y no fuera la continuación de un legado de muerte y terror, pues en San José

Vemos al mirón mirándose, dialogar consigo mismo. En esta compleja relación de miradas, la nuestra también entra en juego.

Revista Iberoamericana, Vol. LXXXI, Núm. 250, Enero-Marzo 2015, 141-157 ISSN 0034-9631 (Impreso)

ISSN 2154-4794 (Electrónico) 
desde hace tiempo se vive bajo un tiempo detenido que coincide con la reducción del individuo a un ser muerto en vida. De aquí que Moraña se pregunte”, “¿Desde dónde habla Ismael? ¿Desde la muerte, desde una memoria que no quiere ni debe morir? (192).

La obfuscación de tiempos, que corresponde a la sensación casi perpetua de estar muerto en vida, se reitera con los tiempos verbales al inicio y al final de la novela ya mencionados. Los ejércitos presenta lo que ocurre entre el paréntesis de la primera frase en pretérito: "Y era así", seguida por la descripción de la atmósfera falsamente plácida y serena del jardín, redefinida más adelante como una "quietud sin sosiego", y la última en futuro, que anuncia la muerte deseada de Ismael: "les diré que no tengo nombre y reiré otra vez, creerán que me burlo y dispararán, así será” (203). Por lo general, lo que caracteriza al futuro es que es deconocido, incierto. Sin embargo, dado el caracter crónico que ha adquirido la violencia, el pronóstico de futuro es repetición de lo mismo. Para los habitantes de San José, el futuro se conoce con certeza: "pase lo que pase será la guerra, resonarán los gritos, estallará la pólvora" (85). En otras palabras, el futuro ha sido vaciado de posibilidad, ha quedado desprovisto de promesa, cambio o expectativa. El hecho de que el futuro se haya vuelto predecible tiene consecuencias devastadoras, indica la eliminación de otras experiencias que no sean las de muerte y miedo.

Ante la experiencia de un tiempo paralizado, Rosero lleva a cabo dos acciones simultáneamente. Por una parte, enfatiza que la violencia no es algo nuevo. Tiene una larga historia, de aquí que haya pasado a aceptarse como costumbre, como parte constitutiva de la vida cotidiana. Si en el pasado "las guacamayas reían", también en el pasado fueron asesinados los padres de Gracielita e Ismael presenció el asesinato de un anciano cuando conoció a Otilia por primera vez. Por otra parte, insiste que "ha cambiado todo" (61) ya que la magnitud, la ubicuidad y las formas de violencia son distintas, como sucede en Colombia y otras partes de América Latina hacia finales del siglo veinte. Para entender el recrudicimento y las nuevas formas de violencia en Colombia a partir de los años noventa, los parámetros usuales para analizar la violencia en Colombia durante la llamada "época de la Violencia" (centrada en el bipartidismo político, como apunta Padilla Chasing) no necesariamente se aplican y exigen nuevas aproximaciones. Lo mismo ocurre con la literatura contemporánea que aborda el tema. A pesar de la larga familiaridad de los personajes con la violencia, Rosero rompe con la apariencia de que se trata de la misma violencia o de que no ha ha sucedido nada, como sugieren los medios, y con la preferencia de algunos de pensar que las cosas siguen como siempre: "La vida en San José retoma su curso, en apariencia" (67); "Estoy en el huerto que permanece igual, como si nada hubiese ocurrido, aunque haya ocurrido todo" (81). Cuando Ismael está en el río, reducido en el presente a un "hilillo que serpentea" (30), comenta que en el pasado las muchachas junto al mismo río, "pronto se tranquilizaban al creer que el mundo alrededor dormía" (40). En contraste con la tendencia a pensar que las cosas no han cambiado, Rosero subraya los signos de catástrofe que estrían la

Revista Iberoamericana, Vol. LXXXI, Núm. 250, Enero-Marzo 2015, 141-157 ISSN 0034-9631 (Impreso)

ISSN 2154-4794 (Electrónico) 
falsa calma y sensualidad del "pueblo de paz", como sarcásticamente se refiere a San José. Se reitera la intensificación del desasosiego bajo el silencio espeso, "idéntico a la niebla", que cubre todo y "nos cierra las caras por todas partes" (85). Descoyuntados por la violencia, tiempo y espacio impiden pensar en el desarrollo de la vida del pueblo como una trayectoria lineal o como un descenso del paraíso al infierno pues el infierno ya está presente en el supuesto escenario paradisíaco del inicio.

\section{EL NOMBRE}

Junto con los tiempo verbales, los nombres y el lenguaje en general también sufren una descapacitación violenta en Los ejércitos. Como observa Moraña, ocurre una "irreversible descomposición del lenguaje" (188). Dentro de este contexto, actos de nombrar, desnombrar y renombrar se vuelven significativos. El nombre del narrador y personaje principal y la manera en que se introduce -"Soy yo. Ismael" (44)- no es accidental; evoca al narrador de Moby Dick -"Call me Ishmael"-, quien también es maestro de escuela y, aún más relevante, testigo y narrador solitario de una catástrofe en la que todos sus compañeros mueren. En el caso de Los ejércitos no todos mueren pero muchos vecinos y amigos, incluyendo la propia esposa de Ismael, desaparecen o son eliminados y la mayoría se ve forzada al desplazamiento como única salida a una situación de emergencia. Como Moby Dick, Los ejércitos es un testimonio ficticio de un sobreviviente que ha presenciado el desgarre de una colectividad sometida a una violencia continua. Thomas Dumm lee este clásico norteamericano como una novela que confronta los genocidios de identidad y poder que atormentan la psique norteamericana y que se han evadido hasta nuestros días (87). Citando a Eyal Peretz, Dumm explica:

Moby Dick is the narrative of Ishmael, the single survivor and sole witness to a horrendous disaster at sea in which all his friends were killed and brought to an early, stoneless and unmarked grave. As if wanting to share his friends' destiny, he has left his given name at sea and has adopted the Biblical name Ishmael, thus indicating his abandonment and loss. From now on he wishes to be called Ishmael and not by his given name, which remains forever unknown. The story we are about to hear is his testimony, the testimony of a survivor. (73)

Siguiendo esta lectura, podría decirse que Los ejércitos ofrece una lectura de la psique colombiana por parte de un sobreviviente ficticio de una catástrofe contemporánea, como lo indica su decisión de no marcharse del pueblo, a diferencia de la mayoría: "Comeré de lo que hayan dejado en sus cocinas, dormiré en sus camas, reconoceré sus historias según sus vestigios [...]" (194). Por un lado, el nombre de Ismael tiene 
resonancias bíblicas y literarias. ${ }^{5}$ Por otro, es significativo que su decisión final de arrojar una carcajada coincide con la renuncia al nombre propio, a la identificación: “[ ... ] les diré que me llamo Jesucristo, les diré que me llamo Simón Bolívar, les diré que me llamo Nadie, les diré que no tengo nombre y reiré otra vez..." (203). La insistencia en la anonimidad recuerda la escena de los cíclopes de la Odisea de Homero. Dado que la novela está enmarcada por una cita de Molière respecto a los peligros mortales de la parodia - “¿No habrá ningún peligro en parodiar a un muerto?”- las resonancias que suscita el nombre de Ismael podrían considerarse como elementos paródicos de estas grandes épicas clásicas, como un comentario sobre la necesidad de reconsiderar lo que significa una narrativa épica en el presente porque el deambular y la sobrevivencia de Ismael en San José, aunque sea en condición casi de zombie, pueden verse como actos épicos en sí.

Junto con lo que ocurre con los nombres, otra manera de marcar cambios en el carácter de la violencia es la erosión de figuras retóricas que acompaña la desfiguración física y social del lugar y complica la aparente legibilidad y coherencia narrativa de Los ejércitos. Al principio está presente el uso de sinestesia y de metáforas o imágenes sensoriales. Estas figuras retóricas, sin embargo, decaen mientras más avanza la narración. Al inicio, por ejemplo, se refiere a Geraldina como "insecto iridiscente", "saltamontes esplendente, [...] acobijada bajo la sombra de los guayacanes [...] rozada por los brazos centenarios de la ceiba" (15), a su risotada "era una bandada de palomas explotando [...]" (17), o al silencio, como algo que "también se ve como el suspiro. Es amarillo, se desliza por los poros de la piel igual que la niebla sube por la ventana" (25). Imágenes más estáticas - cadáveres violentados, esfinges de piedra, "ídolos de dolor" (104), silencio y más sombras- van tomando su lugar. Como parte del trato paródico de representaciones idílicas, Rosero a su vez parodia ciertos usos de lenguaje adjetivado que resultan obsoletos y absurdos dadas las circunstancias actuales, como las líneas del poema que Ismael, en sus años de maestro, les hacía memorizar a sus alumnos: "Y esta magnífica alfombra, oh Tierra quién te la dio, y árbol tanto y fresca sombra [...]” (87).

\footnotetext{
5 Hay otros ecos literarios en Los ejércitos además del nombre de Ismael. Su apellido, Pasos, que resulta irónico dada la dificultad que tiene en caminar o dar pasos por la rodilla adolorida, podría leerse como una referencia paródica a Los pasos perdidos de Alejo Carpentier. También se evoca a Ulíses en la última oración cuando Ismael se ve enfrentado a sus verdugos: “...les diré que me llamo Nadie...” (203). Estas resonancias literarias, aunque tácitas, insertan a la novela dentro del contexto de narrativas épicas de búsqueda y recorrido, si bien en el caso de Ismael sólo se trate de "un merodeo por calles explotadas y casas despedazadas" (126). Es decir, podría leerse a Los ejércitos como una parodia de viajes literarios de auto-descubrimiento, transformación y retorno. El deseo de morir, de poner fin al absurdo, y la incapacidad de llegar al fin, que obliga a continuar a dar pasos dificultuosos, a su vez podría evocar la condición de los personajes cojos y tartamudeantes de Samuel Beckett.
}

Revista Iberoamericana, Vol. LXXXI, Núm. 250, Enero-Marzo 2015, $141-157$ ISSN 0034-9631 (Impreso) ISSN 2154-4794 (Electrónico) 
LA RISA

La risa es otro más de los elementos recurrentes que padecen una erosión progresiva a lo largo de la novela y cuyas asociaciones comunes se resignifican. Se menciona tanto en la primera como en la última oración, con toda una gama de modulaciones o gradaciones entre principio y fin que marcan la acelerada degradación de la vida en San José. Los ejércitos abre con la siguiente oración: "Y era así: en casa del brasilero las guacamayas reían todo el tiempo" (11) y culmina con ésta otra: "[...] les diré que no tengo nombre y reiré otra vez, creerán que me burlo y dispararán, así será” (203). Entre pretérito y futuro, la risa recorre un camino complejo y tortuoso a lo largo de la novela, adquiriendo múltiples funciones, desde signo de falso bienestar, alegría y tranquilidad, pasando por la ironía, la indiferencia, la amargura, hasta manifestarse como posible instrumento de resistencia y provocación, como el único antídoto disponible contra el miedo que ha invadido cuerpo y mente.

Inicialmente la risa es parte de la imagen de aparente serenidad y sensualidad con la que abre la novela en el pretérito, pero esta imagen queda desmantelada muy pronto ya que nos enteramos desde el primer párrafo que la aparente tranquilidad de la escena inicial ya está marcada por la violencia y la incomunicación. Después de todo, uno de los habitantes de este espacio, Gracielita, es huérfana a raíz de que sus padres murieron "cuando ocurrió el último ataque a nuestro pueblo de no se sabe todavía qué ejército" (12). La descripción ya mencionada del cuchillo en la segunda página, que destella al deslizarse enjabonado entre las manos de la jóven muchacha que mece sus caderas mientras lava, a su vez prefigura la violencia por venir: "un cuchillo dentado asomaba, luminoso y feliz, pero en todo caso como ensangrentado" (12). La risa continua de las guacamayas con la que abre la novela se vuelve esporádica unas páginas más adelante y hacia la mitad de la novela se apaga por completo, llega a su fin como expresión corpórea, espontánea. Entre las risas más destacadas está la “ancha" risotada de Geraldina en el jardín, que se compara con "una bandada de palomas explotando intempestiva a la orilla del muro" (17). De aquí en adelante, la risa se irá desnaturalizando; perderá sensualidad y se tornará profundamente incómoda, esquelética, enfermiza, escaso dejo de una subjetividad reducida o aniquilada. Hay referencias a risas desconsoladas, a risas de asombro, rabia o desesperación, que se confunden con el llanto. La cara de risa de Ismael en un momento se describe como "desacorde con la angustia" que vive Hortensia desde la desparición de su esposo, Marcos Saldarriaga (110). En ciertos momentos, la risa se menciona como una mera reacción instintiva ante el miedo: risotadas de miedo, de desquiciamiento e impotencia.

En la última oración, sin embargo, la risa adquiere un caracter paradójico de relativo amparo y desafío; abre un espacio de indeterminación, cuyo efecto queda fuera del marco de la novela ya que la idea de soltar una carcajada se da en futuro: "Reiré otra

Revista Iberoamericana, Vol. LXXXI, Núm. 250, Enero-Marzo 2015, 141-157 ISSN 0034-9631 (Impreso)

ISSN 2154-4794 (Electrónico) 
vez, creerán que me burlo y dispararán, así será” (203). La risa aquí parece ser parte de una estrategia calculada por parte de Ismael para obtener la muerte deseada y poner fin al horror, interrumpir la impotencia, la condición de avanzar "sin saber adónde" (62) a la que ha sido reducido. No connota alegría ni tampoco es signo de superioridad, burla o alivio, ni incluso de nihilismo. Ismael no piensa en reirse con ni de sus probables asesinos, sino simplemente para provocar un desenlace. En este sentido funciona como un desafío, como una afirmación, si bien desoladora, de la escasa posibilidad de actuar. De ser expresión de una ilusoria atmósfera de vitalidad, de un jardín rechinante de luz en una mañana de música y sol - "una risotada unánime y cantarina me rodea" (33) - la risa culmina como afronta y afirmación ante el miedo perpetuo: "arrojar[é] la carcajada impredecible que me ha amparado todo el tiempo" (194). Después de la última risa, pensada más que expresada, deja sentirse un silencio pesado en el que los rasgos pictorescos del primer capítulo quedan sepultados junto con huesos, vidas y tiempos dislocados.

La decisión final de Ismael de soltar una carcajada ante los soldados reducidos a “perfil[es] babeante[s]" que apuntan contra él puede leerse de varios modos. Por un lado señala la enorme impotencia del personaje, la falta de salida. Por otra parte podría ser una manera de introducir lo que Gilles Deleuze llama "una línea de vuelo", línea que no tiene que ver con una fuga o un escape ni con la intención de salvación o restitución. Una línea de vuelo, afirma Deleuze, no consiste en huir de la vida hacia lo imaginario, sino en producir lo real, crear vida, encontrar un arma. ${ }^{6}$ ¿Pero qué significaría "crear" o "producir lo real?" en el contexto de Los ejércitos? Soltar una carcajada, como planea hacerlo Ismael, equivale a actuar en una situación en que la agencia ha sido eliminada y a introducir un elemento imprevisible ante la adversidad. La risa desnaturalizada que se anuncia al cierre de la novela y cuyos efectos se salen del marco de la misma, adquiere el caracter de una disonancia extrema que resalta la desnaturalización de la vida cotidiana vivida por los personajes e introduce una indeterminación que podría albergar o abrir un potencial crítico en un futuro no especificado.

La idea de imaginar un futuro diferente y reestablecer un orden social que no estuviera regulado por la violencia no se vislumbra como una posibilidad al final de Los ejércitos. Sin embargo, en cierta medida, Ismael logra rebelarse ante una realidad apabullante que incapacita al individuo y desarticula la capacidad de resistir o actuar,

\footnotetext{
6 Según Deleuze, individuos y grupos están hechos de distintos tipos de líneas, entre las que distingue tres: 1) líneas de segmentación rígida, como la familia, la profesión, el trabajo, la escuela, 2) líneas que también segmentan pero que actúan más bien como flujos "moleculares" y que pueden introducir pequeñas modificaciones o desviaciones en la trayectoria de un individuo o grupo, y 3) líneas de vuelo o velocidad. Cada una conlleva tanto posibilidades como riesgos, pero ésta última, que Deleuze define como lo opuesto a un destino, se distingue por su capacidad de transportarnos a destinaciones desconocidas, imprevisibles (Dialogues 124-5).
}

Revista Iberoamericana, Vol. LXXXI, Núm. 250, Enero-Marzo 2015, $141-157$ ISSN 0034-9631 (Impreso)

ISSN 2154-4794 (Electrónico) 
al decidir no huir y enfrentar el horror sin irse del pueblo. Su "triunfo" en gran medida radica en su decisión de quedarse en San José acompañado por la risa impredecible, en no abandonar el lugar aún cuando se ha borrado toda posibilidad de cultivar una cotidianidad no marcada por el terror y la violencia. Ismael, como el escritor, en contraste con los periodistas que sólo aparecen en escena para picotear los restos como aves de rapiña, insiste en permanecer y actuar como testigo de la historia y de una colectividad desarmada, rechazando el silencio, la resignación, o el exilio como alternativas. Cerca del final Ismael decide enfrentar la muerte cara a cara: "Me incorporo. [...] Para allá voy" (195). Toma la iniciativa de reirse ante sus verdugos y vencer el miedo, logro que paradójicamente implica tomar el riesgo de desintegración.

A través de la risa, sin ilusiones y sin pretensión de restitución alguna (como la novela misma), Ismael encuentra un modo de actuar sobre la impotencia que se ha ido acumulando ante una violencia sostenida y pasa de una posición pasiva a una activa respecto a su desgracia y la del pueblo. En un ensayo sobre Sarah Kofman, Ann Smock observa que el humorista "simultáneamente pierde y alcanza una posición feliz. Podría decirse que pierde su identidad y a la vez lo corona... El humor enturbia la simple oposición entre victoria y derrota, dominio y abyección. Habita alegremente en la desesperación" (37). Lo que dice Smock respecto al trabajo de Kofman, donde "la hilaridad y la desesperación son dobles y el triunfo no puede ser desentrañado de la humillación" (traducción mía, 37) puede decirse de la ambigüedad de la risa en la obra de Rosero. Smock añade: "Whoever can laugh...at the apparent significance of his difficult undertakings in the so-called real world, as well as at the worries that harass him and the dread he feels, sets himself well above any harm that failure or humiliation could do him From that vantage point nothing that threatens or belittles him appears very important" (34). La conexión que Smock establece entre la risa y el simultáneo abandono y recuperación de la identidad también se aplica a la risa en Los ejércitos puesto que la decisión de soltar una carcajada, como ya dije, coincide con el abandono del nombre propio y/o la adquisición de múltiples nombres posibles: "Su nombre", gritan, "o lo acabamos", que se acabe... "Su nombre", repiten. Les diré que me llamo Jesucristo, les diré que me llamo Simón Bolívar, que me llamo Nadie, les diré que no tengo nombre y reiré otra vez [...]" (203). Con estos nombres que presenta como intercambiables, Rosero se distancia de la ilusión de salvación o redención que conllevan. "La risa", Smock subraya, "tuerce el cuello del significado y abre un espacio de indeterminación". Ni signo de lo cómico ni necesariamente de ironía o burla, la risa simplemente se presenta aquí como una forma preferible al llanto o a la mudez, como expresión sin significado específico, contra la resignación y la impotencia. Reirse aquí implica distanciarse, salirse de uno mismo desde uno mismo, romper hábitos. Es parte de un ultimo esfuerzo por salir de la osificación del sentir y el pensar. Como reir para Ismael, escribir para Rosero sería el modo frágil de confrontar "el desasosiego que se

Revista Iberoamericana, Vol. LXXXI, Núm. 250, Enero-Marzo 2015, 141-157 ISSN 0034-9631 (Impreso)

ISSN 2154-4794 (Electrónico) 
apodera de todo" (83), parte de esa búsqueda tenaz "sin horizonte" (En el lejero 43) recurrente en sus novelas, de un esfuerzo por salir del enmudecimiento y la parálisis generados por el miedo.

En tanto que la risa del final es lo opuesto a la dulce risa de las guacamayas en la primera oración, la novela llama la atención sobre todo a una redefinición de registro, de tono como aspecto central a la narrativa. La risa final es un gesto deliberado, vaciado de espontaneidad y sensualidad, cargado de ambivalencia, en el que se mezclan desesperación, amargura, locura y desafío. Ni afirmación ni negación, la carcajada de Ismael implica un último esfuerzo por forjar una salida, una táctica al borde de la muerte que consiste en soltar algo que resista la codificación. En tanto que no escuchamos la risa que Ismael piensa arrojar, resulta dificil captar los múltiples matices y posibles significados de la misma; queda suspendida en el umbral de una zona de gran precariedad, como un fantasma por aparecer, sin resolución, parecida a la sonrisa enigmática y desestabilizadora, sin cuerpo, del gato de Cheshire.

\section{EL PAPEL DE LA FICCIÓN}

El trabajo con la risa en Los ejércitos a su vez marca una brecha entre la novela y otras formas de comunicación cultural. En la novela hay varias referencias al periodismo y a la televión que le permiten a Rosero comentar sobre la diferencia entre recibir información de lo que ocurre en un lugar como San José a través de medios de comunicación masivos o leer una novela en la que la relación entre ficción y realidad es compleja y borrosa. Las diferencias son evidentes y sugieren que para Rosero la novela puede ofrecer una posición alternativa a los medios masivos de comunicación, que tienden a favorecer a los muertos sobre los vivos, a ignorar el antes y después de actos atroces, y a fomentar el sensacionalismo con el fin de causar un impacto en el espectador o lector, reduciéndolo a un simple mirón pasivo, sin contribuir a contrarrestar la impotencia generada por la violencia.

Las imágenes gráficas de violencia con las que suelen saturarnos los medios tienden a buscar el impacto inmediato más que la comprensión y a erosionar más que a agudizar la sensibilidad o la capacidad crítica y ética. Paul Virilio observa cómo las imágenes televisas desde fines del siglo pasado "[...] nos han hecho asistir (en directo) a una continua escalada en material de difusión del espanto". Con los medios audiovisuales contemporáneos asistimos "pasmados a la sobreexposición de accidentes, de catástrofes de toda clase, por no hablar de las guerras" (49). El texto literario, además de implicar un trabajo sobre la lengua, no se limita a proporcionar datos, a explicar o a representar.

En Los ejércitos, la información que se transmite en los medios, además de llegar atrasada, suele ser distorsionada y tendenciosa -“el presidente afirma que aquí no pasa nada ni que aquí ni en el país hay guerra” (161)-. No casualmente, la periodista que

Revista Iberoamericana, Vol. LXXXI, Núm. 250, Enero-Marzo 2015, 141-157 ISSN 0034-9631 (Impreso)

ISSN 2154-4794 (Electrónico) 
llega a San José para cubrir la noticia más reciente y que a Ismael le parece "pertenecer a otro mundo" (134), es sobrina del general, sugiriendo así la colusión entre medios informativos y poder. Los periodistas llegan a San José cual buitres, sólo cuando aumenta la pila de cadáveres, sólo cuando ofrece material para transformar el horror de la violencia en espectáculo. Contra esta espectacularización y banalización de la violencia, Rosero ofrece una perspectiva interna al narrar la historia del deterioro progresivo de San José a través de Ismael, quien conoce bien la historia del pueblo y sus habitantes y se dedica principalmente a observar y a registrar los eventos.

Coincido con Hoyos cuando dice que Los ejércitos ofrece una escenificación alternativa de la violencia, que a su vez invita a repensar la mirada de las escenas que se despliegan ante nosotros. Si los medios televisivos y periodísticos ofrecen un espejo distorsionado a la población -en el noticiero los habitantes de San José se ven retratados "por primera vez ... rodeados de muertos" (74)- la novela hace hincapié en la desfiguración de la imagen reflejada en estos otros espejos y ofrece otro que se reconoce resquebrajado, como el del baño en la terminal de autobuses donde Ismael conoce a Otilia por primera vez. Rosero resiste la deslocalización de referentes locales de la violencia, que, como Rueda observa, tienden a disiparse en la manera en que la ficción que trata el tema suele circular dentro del mercado global actual. En contraste, ofrece una mirada más íntima al respecto, aún si la intimidad, como anota Marín Colorado, "no se constituye como un espacio de plenitud" (148). Ante la anonimidad a la que suelen quedar reducidas las víctimas, Rosero nos familiariza con los habitantes de San José (no con sicarios, matones, o narcotraficantes, frecuentes en otras producciones literarias y culturales colombianas), con las relaciones entre vecinos, las calles y las actividades del pueblo. A través de un narrador inocuo, si bien también sarcástico, lujorioso y crítico, nos comunica una idea de la cotidianidad y el modo acelerado en que se va descomponiendo. Sobre todo, ofrece una mirada indagadora, invitando al lector a hacer lo mismo: a cuestionar lo que mira y a reconsiderar su posición como posible voyerista de la violencia. Para Moraña,"cada lector se convierte, también, en un voyerista, inescapablemente seducido por los trayectos que va siguiendo el errático e inoportuno erotismo del protagonista" ("Violencia y sublimidad" 191). Aunque no me atrevo a hacer tal aseveración, ciertamente, mirada y voyerismo recurren en la obra de Rosero y revierten en el lector.

La conexión entre erotismo y violencia en Los ejércitos es innegable, pero difiere de novelas más conocidas que trabajan sobre modalidades de la violencia reciente en Colombia -pienso sobre todo en La virgen de los sicarios (1994) y Rosario Tijeras (1999)- en que, como señala María Helena Rueda en La violencia y sus huellas, la violencia se trabaja casi exclusivamente por vía del erotismo. Rosero desarrolla otras estrategias. Los elementos eróticos en Los ejércitos terminan siendo contaminados como todo lo demás. Lo que ocurre con Geraldina lo deja claro: la violencia destruye

Revista Iberoamericana, Vol. LXXXI, Núm. 250, Enero-Marzo 2015, 141-157 ISSN 0034-9631 (Impreso)

ISSN 2154-4794 (Electrónico) 
la pulsión erótica que caracteriza la mirada inicial de Ismael. La risa tomará su lugar, gesto que, como ya resalté, coincide con el abandono del nombre propio.

Resulta significativo que la risa final se enuncia en futuro. Dada la alteración de la temporalidad bajo la violencia, el uso de verbos en futuro hacia el final de la novela y en la última oración en particular, alude a las posibilidades de la ficción, por más ténues que éstas puedan ser:

Comeré de lo que hayan dejado en sus cocinas, dormiré en sus camas, reconoceré sus historias según sus vestigios, [...] mi tiempo será otro tiempo, [...] no soy ciego, sanará mi rodilla, caminaré hasta el páramo como un paseo y después regresaré, [...] ¿voy a llorar?, no, sólo arrojar la carcajda impredecible que me ha amparado todo el tiempo. (194)

Comeré, dormiré, reconoceré, será, sanará, caminaré, regresaré, reiré. Esta reiteración de formas verbales en futuro de acciones cotidianas que han sido drásticamente alteradas sugiere que la ficción puede abrir una posibilidad de futuro, no uno utópico en que se anuncia o prefigura una comunidad por venir o se ofrece consuelo, lo cual estaría muy lejos del panorama presentado en la novela, sino uno iniciado por una decisión consciente de desafiar la muerte a la que la vida ha sido reducida y que consiste en poner fin al miedo como experiencia dominante, en reir en vez de seguir actuando como un muerto para despistar a la muerte. Este uso de futuro contrasta con el del primer capítulo, donde el tiempo verbal implica promesas que no serán cumplidas, como las que le hace Geraldina a Gracielita: “'Cuando cumplas quince años', [...] 'te entregaré religiosamente tu dinero [...] Podrás estudiar modistería, serás una mujer de bien, te casarás, seremos los padrinos de tu primer hijo [...]" (13).

Si bien no es difícil imaginar que la risa final de Ismael resultará en su muerte -“dispararán”- ésta conlleva una calma paradójica que no tiene que ver con la engañosa serenidad de la escena inicial: "Me dirijo a mi casa, avanzo por la calle tranquilamente, sin huir, sin volverme a mirar, como si nada de esto ocurriera -mientras ocurre" (203 cursiva mía). Para concluir, quisiera reiterar el paralelo entre la idea de soltar la risa y la desidentificación de Ismael en la última oración al abandonar el nombre propio. Al renunciar a su nombre, acto ligado a su decisión de reir como su última acción, puede decirse que Ismael busca una línea de vuelo que, como sugerí anteriormente, no consiste en escapar del mundo ni en renunciar a la acción. La risa y el sacudimiento corpóreo que la acompaña, se convierten en un arma potencial a través de la cual se busca romper con la familiaridad con la muerte a la que se ha reducido la vida y con la temporalidad indiferenciada instaurada por el terror. La risa sustituye al lenguaje que ha quedado inutilizado. Como la bandada de palomas que libera Geraldina con su carcajada al inicio, "explotando intempestiva a la orilla del muro", la risa de Ismael actúa como un explosivo potencial. Con esta risa por ser soltada, la novela da un paso simbólico frente

Revista Iberoamericana, Vol. LXXXI, Núm. 250, Enero-Marzo 2015, 141-157 ISSN 0034-9631 (Impreso)

ISSN 2154-4794 (Electrónico) 
a la aniquilación, un paso incierto como el que puede dar un sujeto exhausto con el alma y las rodillas adoloridas, para salir de ese paño de niebla que desciende sobre San José.

¿Qué es lo que ofrece entonces Los ejércitos? La transposición de una experiencia individual y colectiva a un tipo de conocimiento literario que alerta sobre la urgente necesidad de alterar hábitos y resistir la internalización de la violencia y el miedo como parte constitutiva de la vida cotidiana. Rosero invita a una lectura crítica tanto del presente como del pasado, como un paso necesario para interrumpir la continuidad de una experiencia destructiva, de duración indefinida, que impide la posibilidad de otras experiencias.

No sorprende que la novela de Rosero posterior a Los ejércitos sea La carroza de Bolivar (2012) ya que aquí se continúa el proceso de una lectura crítica de presente y pasado al insistir en la necesidad de releer la historia de Colombia desde la independencia y desmitificar la figura de Bolívar como máximo héroe nacional. En La carroza de Bolivar, el Doctor Proceso, personaje principal que lleva veinte años investigando la figura del libertador, pone "en proceso" a Bolívar e incita a una relectura de la historia colombiana. Como una carroza carnavalesca, la ficción se adentra en la historia oficial (como en Los ejércitos se adentra en la violencia) para socavar construcciones de sentido aceptadas que contribuyen a mantener la ilusión de progreso y liberación, para sacudir, como lo hace la risa de Ismael, hábitos, costumbres y conductas sociales que adormecen o incluso incapacitan, no sólo a individuos sino a la sociedad entera. La novela pasa así a ser una manera de librar una batalla a través de la palabra escrita frente a múltiples ejércitos, pasados y presentes.

He querido sugerir que mediante el juego con los tiempos y el poder ambivalente de una risa que arriesga todo, Rosero evade los peligros de una lectura simplista de formas finiseculares de la violencia e invita a reflexionar sobre cómo leer/mirar la violencia, a re-sensibilizar la mirada, irónicamente a través de una imagen auditiva muda. Se sale del esquema del que habla María Helena Rueda como característico de novelas de violencia en Colombia a partir de los noventa, que suelen presentarla "como un hecho acabado" (La violencia y sus huellas 163). La novela queda abierta con el fantasma de una risa imprevisible y llagada, a punto de ser liberada mas aún no escuchada. De esta manera, "se lanza hacia aquello que desconoce", como dice David Oubiña respecto al arte según Adorno, que "lo transformará indefectiblemente" (29). En este caso, el paso es hacia la muerte casi segura, pero diferente al menos de la muerte en vida que Ismael ha padecido hasta ese momento en su obstinada espera del regreso improbable de Otilia. El potencial de dicha risa, de sacudir y perturbar una condición de desamparo e impotencia radical, implica, sin embargo, asumir un gran riesgo: aceptar el desmoronamiento, la coincidencia entre la decisión de actuar y el momento de aniquilamiento, es decir, aceptar ser nadie, tomar una posición que conlleva abandonar la subjetividad familiar para quizá reinventarla en una forma aún desconocida.

Revista Iberoamericana, Vol. LXXXI, Núm. 250, Enero-Marzo 2015, 141-157 ISSN 0034-9631 (Impreso)

ISSN 2154-4794 (Electrónico) 


\section{OBRAS CITADAS}

Deleuze, Gilles y Claire Parnet. Dialogues II. Hugh Tomlinson y Barbara Habberjam, trads. Nueva York: Columbia UP, 2007.

Dumm, Thomas. "Having." Loneliness as a Way of Life. Cambridge: Harvard UP, 2008.

Hoyos, Héctor. "Visión desafectada y resingularización del evento violento en Los Ejércitos de Evelio Rosero". El lenguaje de las emociones: afecto y cultura en América. Mabel Moraña, ed. Madrid: Iberoamericana, 2012. 283-295.

Marín Colorado, Paula Andrea. "La novelística de Evelio Rosero Diago: los abusos de la memoria". Cuadernos de Aleph 3 (2011): 136-160.

Maya Franco, Claudia María. "Los ejércitos de Evelio Rosero y la narración de la violencia en Colombia". Lingüística y Literatura 61 (2012): 233-240.

Moraña, Mabel. "Violencia, sublimidad y deseo en Los ejércitos de Evelio Rosero". La escritura del límite. Madrid: Iberoamerica, 2010. 185-202.

"Poscríptum. El afecto en la caja de herramientas". El lenguaje de las emociones: afecto y cultura en América. Mabel Moraña, Ignacio Sánchez Prado, eds. Madrid: Iberoamerica, 2012. 313-337.

Oubiña, David. El silencio y sus bordes: modos de lo extremo en la literatura y el cine. Buenos Aires: Fondo de Cultura Económica, 2011.

Padilla Chasing, Ivan Vicente. "Los ejércitos: novela del miedo, la incertidumbre y la desesperanza”. Literatura: Teoría, Historia, Crítica 14/1 (2012): 121-158.

Rosero, Evelio Diago. Los ejércitos. México: Tusquets Editores, 2007. En el legero. México: Tusquet Editores, 2013.

La carroza de Bolívar. México: Tusquets Editores, 2012.

Rueda, Maria Helena. La violencia y sus huellas: una mirada desde la narrativa colombiana. Frankfurt: Vervuert, 2011.

"Dislocaciones y otras violencias en el circuito transnacional de la literatura latinoamericana". Revista de Crítica Literaria Latinoamericana XXXV/69 (2009): 69-90.

Smock, Ann. “Sarah Kofman's Wit.” Sarah Kofman's Corpus. Tina Chanter y Pleshette de Armitt, eds. Nueva York: State U of New York P, 2008.

Suárez, Juana. Sitios de contienda: producción cultural colombiana y el discurso de la violencia. Frankfurt: Vervuert, 2010.

Virilio, Paul. El accidente original. Buenos Aires: Amorrortu Editores, 2010.

Revista Iberoamericana, Vol. LXXXI, Núm. 250, Enero-Marzo 2015, 141-157 
